\title{
The inositol trisphosphate pathway mediates platelet-activating-factor-induced
} pulmonary oedema

\author{
R. Göggel and S. Uhlig
}

ABSTRACT: Platelet-activating factor (PAF) is a pro-inflammatory lipid mediator that increases vascular permeability by simultaneous activation of two pathways, one dependent on the cyclooxygenase metabolite prostaglandin $\mathrm{E}_{2}$ and the other on the sphingomyelinase metabolite ceramide. The hypothesis that part of the PAF-induced oedema is mediated via the inositol 1,4,5trisphosphate $\left(\mathrm{IP}_{3}\right)$ pathway or Rho kinase pathway was investigated.

Oedema formation was induced in isolated perfused rat lungs by injection of 5 nmol PAF into the pulmonary artery. Lungs were pre-treated with specific inhibitors: edelfosine (L108) to block phosphatidyl-inositol-specific phospholipase $\mathrm{C}$, xestospongin to block the $\mathrm{IP}_{3}$ receptor, 5iodonaphthalene-1-sulphonyl-homopiperazine (ML-7) to block myosin light chain kinase, and (+)R-trans-4-(aminoethyl)-N-(4-pyridyl)cyclohexanecarboxamide (Y27632) to block Rho-associated protein kinase.

Pre-treatment with L108 or xestospongin reduced PAF-induced oedema formation by $\mathbf{5 8}$ and $56 \%$, respectively. The effect of $L 108$ was additive to that of the cyclooxygenase inhibitor acetyl salicylic acid (88\% oedema reduction). PAF-induced oedema formation was also reduced if extracellular calcium concentrations were lowered. Furthermore, treatment with ML-7 reduced oedema formation by 54\%, whereas Y27632 was without effect.

It is concluded that platelet-activating-factor-triggered oedema is mediated by activation of the inositol 1,4,5-trisphosphate pathway, influx of extracellular calcium and subsequent activation of a myosin light chain kinase-dependent and Rho-associated-protein-kinase-independent mechanism.

KEYWORDS: Calcium, myosin light chain kinase, phosphatidyl-inositol-specific phospholipase C, Rho kinase

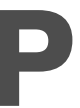
latelet-activating factor (PAF) affects a variety of different lung functions, such as airway tone, vascular tone, ciliary beating frequency and endothelial permeability. Accordingly, PAF has been implicated in lung diseases such as acute respiratory distress syndrome [1] and asthma [2]. Among these actions of PAF, the mechanisms of the pressor responses are known to depend on thromboxane and peptidoleukotrienes [3], mainly via activation of the Rho kinase pathway [4]. The molecular mechanisms of PAF-induced oedema formation have only recently been studied in greater detail.

PAF induces oedema by activation of two lipidmodifying enzymes, cyclooxygenase (COX) and sphingomyelinase, which give rise to the formation of prostaglandin $E_{2}$ and ceramide $[5,6]$. The signalling pathways through which these lipid mediators alter vascular permeability are largely unknown. The actions of prostaglandin $E_{2}$ depend on voltage-gated potassium channels in a poorly understood manner [5], whereas the non-COX-dependent pathway is blocked by quinolines such as quinine, quinidine and chloroquine [7]. Among the known molecular targets of quinolines are the inositol 1,4,5-trisphosphate $\left(\mathrm{IP}_{3}\right)$ receptors [8], phospholipase $\mathrm{A}_{2}$ and particular group of currently 11 PLCs, called phosphoinositide-specific PLC (PI-PLC) isozymes, triggers the rapid hydrolysis of membrane phosphatidylinositol 4,5-bisphosphate to generate two intracellular messengers, diacylglycerol and $\mathrm{IP}_{3}[12,13]$. While diacylglycerol activates protein kinase $\mathrm{C}(\mathrm{PKC}), \mathrm{IP}_{3}$ rapidly releases $\mathrm{Ca}^{2+}$ from intracellular $\mathrm{Ca}^{2+}$ pools within the endoplasmic reticulum and other cellular membranes by binding to the $\mathrm{IP}_{3}$ receptor (IP3R). phospholipase C (PLC) isoenzymes [9-11]. A
AFFILIATIONS

Division of Pulmonary Pharmacology, Research Centre Borstel, Leibniz Centre for Medicine and Biosciences, Borstel, Germany.

CORRESPONDENCE

S. Uhlig

Division of Pulmonary Pharmacology

Research Centre Borstel

Leibniz Centre for Medicine and

Biosciences

Parkallee 22

D-23845 Borstel

Germany

Fax: 494537188778

E-mail: suhlig@tz-borstel.de

Received:

June 112004

Accepted after revision:

December 272004

SUPPORT STATEMENT

This study was supported by the German Research Foundation within Collaborative Research Centre 367 TPA9

European Respiratory Journal Print ISSN 0903-1936 Online ISSN 1399-3003 
Increased cytosolic $\mathrm{Ca}^{2+}$ levels regulate a plethora of intracellular processes, among them smooth muscle contraction [14] and vascular permeability [15]. The $\mathrm{Ca}^{2+}$ signals are sensed by calcium-binding proteins, of which calmodulin is the most important. Many G-protein-coupled receptors are known to activate PI-PLC, among them PAF. Since, in mesangial cells, PAF has been shown to raise intracellular $\mathrm{Ca}^{2+}$ concentrations through the $\mathrm{IP}_{3}$ pathway [16] and because $\mathrm{Ca}^{2+}$ has frequently been implicated in oedema formation [17], it was speculated that this pathway might be involved in PAF-induced oedema formation in the lung.

Current models of the development of increased vascular permeability suggest that elevated intracellular $\mathrm{Ca}^{2+}$ concentrations activate myosin light chain kinase (MLCK), which, in turn, results in endothelial cell contraction and thus enhanced permeability $[17,18]$. In addition, a possible contribution of the small guanosine triphosphate (GTP)-binding protein Rho and Rho-associated protein kinase (ROCK) to the loss of barrier function has been described [19]. However, the majority of the current knowledge regarding the role of $\mathrm{Ca}^{2+}, \mathrm{IP}_{3}, \mathrm{MLCK}$ and ROCK in vascular permeability was derived from studies using endothelial cells in culture, mostly with thrombin as a model agent [20]. To date, these mechanisms have not been investigated in the whole intact organ, with the notable exception of a recent study showing reduced oedema formation in response to lipopolysaccharide and overventilation in mice that lacked endothelial MLCK [21]. In addition, the involvement of the $\mathrm{IP}_{3}$ pathway, MLCK and ROCK in PAFinduced oedema has not yet been examined in the whole intact organ.

In vivo, besides bronchoconstriction [22], PAF produces many effects that may contribute to oedema formation, for example, hydrostatic mechanisms, such as activation of neutrophils $[23,24]$, pulmonary vasoconstriction $[25,26]$ and platelet aggregation [24]. Although these factors may aggravate pulmonary oedema, the major factor in PAF-induced oedema formation appears to be increased vascular permeability. It is important to note that the PAF-induced alterations in vascular permeability are independent of neutrophils [27] and platelets [28]. Here, the mechanisms of PAF-induced changes in vascular permeability are investigated using the model of the isolated blood-free perfused rat lung. Compared to the in vivo situation, this model permits the exclusion of oedema formation due to increased hydrostatic pressure by the use of constant pressure perfusion; accordingly, under these conditions, PAF does not alter capillary pressure [3,5]. Conversely, PAF increases the capillary filtration coefficient and vascular permeability $[5,29]$. Thus, in the present model, PAF-induced pressor responses and oedema formation can be completely separated; the pressor responses but not oedema formation are prevented by thromboxane and leukotriene antagonists [7], whereas, conversely, treatment with ceramide antibodies attenuates oedema formation without affecting the pressor responses [6]. In summary, constant-pressure perfused isolated lungs are ideally suited to investigation of the mechanisms of increased vascular permeability in the whole intact organ. Here, this model has been used to investigate the role of the $\mathrm{IP}_{3}$ pathway, extracellular $\mathrm{Ca}^{2+}, \mathrm{MLCK}$ and ROCK in PAFinduced oedema formation.

\section{MATERIALS AND METHODS Study design}

Lungs were always perfused for $10 \mathrm{~min}$ under control conditions (tidal volume 1.8-2 $\mathrm{mL}$, pulmonary artery pressure $10 \mathrm{cmH}_{2} \mathrm{O}$ and perfusate flow rate $30 \mathrm{~mL} \cdot \mathrm{min}^{-1}$ ) before capillary filtration coefficient $(K \mathrm{f}, \mathrm{c})$ measurement, for which the arterial and venous reservoir were raised by $5 \mathrm{~cm}$ for $10 \mathrm{~min}$. The $\mathrm{Kf}, \mathrm{c}$ was also measured $30 \mathrm{~min}$ after addition of PAF (Sigma, Deisenhofen, Germany), which was always injected as a 5-nmol bolus directly into the perfusate (which contained fraction V bovine albumin (Serva, Heidelberg, Germany) to maintain oncotic pressure) after $30 \mathrm{~min}$ of perfusion. All other agents were added to the buffer reservoir. Acetylsalicylic acid (ASA) (Sigma) was made up in bicarbonate solution and added $10 \mathrm{~min}$ before PAF. The phospholipase inhibitor edelfosine (L108) (Biomol, Hamburg, Germany; median inhibitory concentration (IC50) $10 \mu \mathrm{M}$ [30], used at $30 \mu \mathrm{M})$ and the membrane-permeable IP3R antagonist xestospongin C (Biomol; IC50 $0.4 \mu \mathrm{M}$ [31], used at $1 \mu \mathrm{M}$ ) were prepared as stock solutions in ethanol, the MLCK inhibitor 5-iodonaphthalene-1-sulphonyl-homopiperazine (ML-7) (Biomol; IC50 $0.3 \mu \mathrm{M}$ [31], used at $35 \mu \mathrm{M}$ ) in $50 \%$ aqueous ethanol, and the ROCK inhibitor (+)-R-trans-4-(aminoethyl)$N$-(4-pyridyl)cyclohexanecarboxamide (Y27632) (Tocris, Avonmouth, UK; IC50 $0.8 \mu \mathrm{M}[32,33]$, used at $10 \mu \mathrm{M})$ in dimethyl sulphoxide; aliquots from these stock solutions were added $10 \mathrm{~min}$ before PAF. The calmodulin-dependent protein kinase II (CaMKII) inhibitor K252a (Biomol; IC50 2 nM [34], used at $10 \mathrm{nM}$ (IC50 for inhibition of protein kinase A (PKA), PKC and MLCK $20 \mathrm{nM}[35,36]))$ was used to inhibit CaMKII. For the experiments on the role of extracellular $\mathrm{Ca}^{2+}$, the lungs were perfused with Krebs-Henseleit buffer containing different $\mathrm{Ca}^{2+}$ concentrations from the beginning of the preparation. None of the solvents alone had any affect on PAF-induced weight gain (data not shown).

The data on airway and vascular resistance, for most of the experiments shown in the present study, have previously been reported [4], and are therefore not repeated here. However, this information is not pertinent to the present study since, in the present model, oedema formation occurs completely independently of the haemodynamic changes (see introduction).

\section{Isolated perfused rat lung preparation}

The isolated perfused rat lung set-up has previously been described in detail $[37,38]$. Briefly, female Wistar rats (Harlan Winkelmann, Borchen, Germany; mean \pm SD $220 \pm 20 \mathrm{~g}$ body weight) were anaesthetised by intraperitoneal injection of $16 \mathrm{mg} \cdot \mathrm{kg}$ body weight ${ }^{-1}$ pentobarbital sodium (Nembutal ${ }^{\circledR}$; Wirtschaftsgenossenschaft Deutscher Tierärzte, Hanover, Germany). They were intubated with a tracheal cannula and ventilated at 80 breaths $\cdot \mathrm{min}^{-1}$ on room air with a tidal volume of 1.8-2.1 $\mathrm{mL}$. Every $5 \mathrm{~min}$, a deep breath (hyperinflation at $-16 \mathrm{cmH}_{2} \mathrm{O}$ ) was initiated in order to prevent atelectasis. After laparotomy, the diaphragm was removed. The animals were ex-sanguinated and the chest was opened. A ligature was placed around the pulmonary artery and aorta. An arterial cannula was inserted into the pulmonary artery and fixed by the ligature. Then, the apex of the heart was cut off, the venous cannula inserted into the left atrium and fixed by a ligature 
around the heart. The excised lungs were perfused at constant hydrostatic pressure, which resulted in a flow rate of $\sim 30 \mathrm{~mL} \cdot \mathrm{min}^{-1}$ through the pulmonary artery with KrebsHenseleit buffer containing $2 \%$ albumin, $0.1 \%$ glucose and $0.3 \%$ hydroxyethyl piperazine ethanesulphonic acid (HEPES). The total recirculating volume of buffer was $100 \mathrm{~mL}$. The lungs were suspended by the trachea and ventilated by negative pressure ventilation in an artificial thorax chamber. Thorax chamber pressure was measured using a differential pressure transducer, and air flow velocity was measured via a pneumotachograph tube connected to a differential pressure transducer. Lung weight was followed with a specifically designed weight transducer [29]. The Kf,c was measured by fitting the weight gain to a bi-exponential equation, as described previously [39]. Perfusate flow, buffer $\mathrm{pH}$, and arterial and venous pressure were continuously monitored. The $\mathrm{pH}$ of the perfusate before entering the lung was kept at 7.35 by automatic bubbling of carbon dioxide into the buffer.

The data for the control groups (PAF and control) are from experiments performed over recent years, in which it was checked, at regular intervals, that PAF and perfusion without any treatment give the expected responses. These data show that the response to PAF is highly reproducible over time. During studies on the mechanisms of PAF-induced oedema, various hypotheses were followed simultaneously; therefore, the data from the control groups have also been used in previous studies performed at the same time $[5,6]$.

\section{Statistical analysis}

The data in the tables are presented as mean $\pm S D$, and data in the graphs as mean \pm SEM. In case of heteroskedasticity, data were logarithmically transformed prior to analysis. Data were analysed using an unpaired t-test, one-sided or two-sided as indicated. The false discovery rate due to multiple comparisons was controlled by the method of BENJAMINI and HOCHBERG [40]. This procedure controls the false discovery rate, i.e. the expected proportion of false discoveries amongst the rejected hypotheses, and is a less stringent condition than the familywise error rate, making this method more powerful. This method has recently been recommended "as the best practical solution to the problems of multiple comparisons that exist within science" [41]. A p-value of $<0.05$ was considered significant.

\section{RESULTS}

Perfusing lungs with PAF increased lung weight as shown before $[5,29]$. The contribution of the $\mathrm{IP}_{3}$ pathway to PAFinduced oedema was investigated using L108, an inhibitor of PI-PLC, and xestospongin C, a sponge toxin that interferes with the IP3R.

Pre-treating the lungs with $30 \mu \mathrm{M}$ L108 attenuated the PAFinduced increase in lung weight (fig. 1, table 1) and $K \mathrm{f}, \mathrm{c}$ (table 1). As mentioned above, PAF induces oedema via two separate mechanisms that can be blocked by the COX inhibitor ASA and quinine [7]. When the lungs were pre-treated with ASA, oedema formation was reduced by $\sim 34 \%$, and when ASA was co-perfused with L108, the effect of PAF on lung weight gain was almost completely inhibited (fig. 1, table 1). Pre-treatment with xestospongin $\mathrm{C}(1 \mu \mathrm{M})$ attenuated the PAFinduced weight gain and the increase in $\mathrm{Kf}, \mathrm{c}$ to the same extent

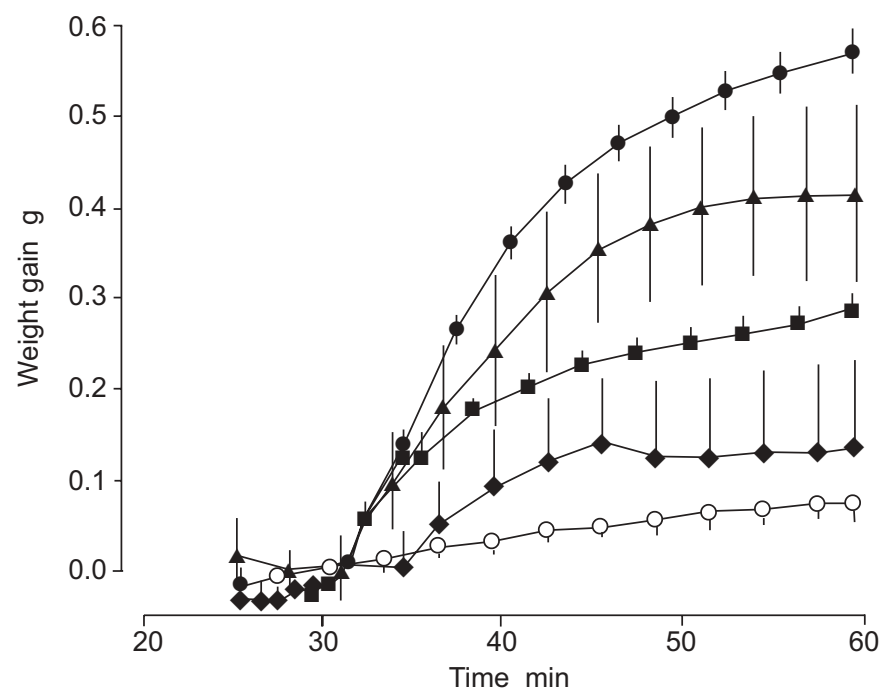

FIGURE 1. Effect of acetylsalicylic acid (ASA) and edelfosine (L108) on platelet-activating factor (PAF)-induced oedema formation ( $\bullet$ : PAF $(n=42)$; $\boldsymbol{\Delta}:$ ASA+PAF $(n=9) ; \boldsymbol{\square}:$ L108+PAF $(n=4) ; \bullet:$ ASA/L108+PAF $(n=4) ; 0$ : control $(n=12))$. PAF was given as a 5 -nmol bolus injection 30 min after beginning the experiment. ASA and L108 were given 10 min before injection of PAF. Data are presented as mean $\pm \mathrm{SEM}$; for statistics, see table 1

TABLE 1 Platelet-activating factor (PAF)-induced oedema formation: inhibition of the inositol 1,4,5-trisphosphate pathway

\begin{tabular}{|c|c|c|c|c|c|}
\hline & Subjects $\mathrm{n}_{1}$ & Weight gain $\mathrm{g}$ & Oedema formation \% & Subjects $n_{2}$ & $\Delta K \mathrm{f}, \mathrm{c} \mathrm{mL} \cdot \mathrm{min}^{-1} \cdot \mathrm{cmH}_{2} \mathrm{O}^{-1} \cdot 100 \mathrm{~g}^{-1}$ \\
\hline Control & 12 & $0.070 \pm 0.060^{\star, \#}$ & 0 & 10 & $-0.057 \pm 0.084^{\star}$ \\
\hline ASA+PAF & 9 & $0.412 \pm 0.097^{\star}$ & 66 & 0 & ND \\
\hline L108+PAF & 4 & $0.289 \pm 0.041^{*, \#}$ & 41 & 3 & $-0.211 \pm 0.218^{*}$ \\
\hline L108/ASA+PAF & 4 & $0.121 \pm 0.196^{\star, \#}$ & 10 & 4 & $-0.070 \pm 0.121^{*}$ \\
\hline
\end{tabular}

Data are presented as mean $\pm S D$, unless otherwise stated. PAF was given as a 5 -nmol bolus injection 30 min after beginning the perfusion. $\Delta K \mathrm{~K}, \mathrm{c}$ : difference in capillary filtration coefficient before and 30 min after injection of PAF; ASA: acetylsalicylic acid; L108: edelfosine; ND: not determined. ": 30 min after application of PAF. *: p<0.05 versus PAF; \#: $p<0.05$ versus ASA+PAF 

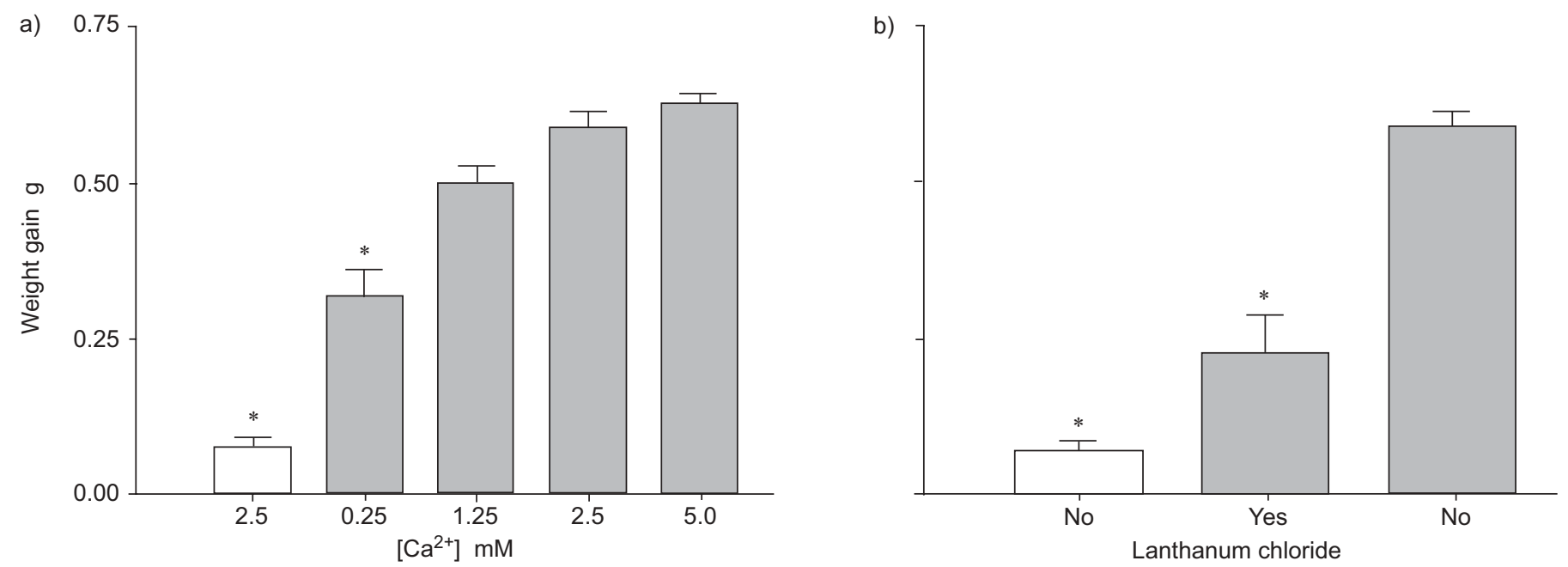

FIGURE 2. Effect on platelet-activating factor (PAF)-induced oedema formation of a) reduced $\mathrm{Ca}^{2+}$ concentration (normal concentration $2.5 \mathrm{mM}$ ) and b) lanthanum chloride $\left(2.5 \mathrm{mM} \mathrm{Ca}^{2+}\right)$. PAF was given as a 5 -nmol bolus injection $30 \mathrm{~min}$ after beginning the experiment $(\square)$, and buffer containing different $\mathrm{Ca}^{2+}$ concentrations was used from the beginning of the experiment ( $\square$ : no PAF). The unspecific $\mathrm{Ca}^{2+}$ channel inhibitor lanthanum chloride was added 20 min before injection of PAF ( $\mathrm{n}=5$ ). Data are presented as mean \pm SEM (no PAF $\left(2.5 \mathrm{mM} \mathrm{Ca}^{2+}\right.$ ): $n=12 ; 0.25 \mathrm{mM} \mathrm{Ca}^{2+}: \mathrm{n}=7 ; 1.25 \mathrm{mM} \mathrm{Ca}^{2+}: \mathrm{n}=3 ; 2.5 \mathrm{mM} \mathrm{Ca}^{2+}: \mathrm{n}=42 ; 5.0 \mathrm{mM} \mathrm{Ca}{ }^{2+}: \mathrm{n}=3$ ). *: $\mathrm{p}<0.05$ versus PAF alone $\left(2.5 \mathrm{mM} \mathrm{Ca}^{2+}\right)$.

as did L108 (table 1). Furthermore, heparin, another agent reported to inhibit IP3Rs [42, 43], had beneficial effects on PAFinduced oedema formation (table 1). However, heparin may bind directly to PAF [44]. Since, in the present experiments, heparin was effective against both oedema formation and pressor responses (data not shown) the possibility that the beneficial effects of heparin were simply due to binding of PAF cannot be excluded.

Activation of the $\mathrm{IP}_{3}$ pathway and subsequent emptying of intracellular $\mathrm{Ca}^{2+}$ stores may lead to activation of storeoperated calcium channels (SOCs) $[45,46]$. In order to examine the importance of extracellular $\mathrm{Ca}^{2+}$, lungs were perfused with different $\mathrm{Ca}^{2+}$ concentrations. These experiments were difficult to carry out, since reduced extracellular $\mathrm{Ca}^{2+}$ itself may enhance permeability in perfused lungs [47, 48]. The lowest $\mathrm{Ca}^{2+}$ concentration tolerated was $250 \mu \mathrm{M}$. Reduction of extracellular $\mathrm{Ca}^{2+}$ concentration reduced PAF-induced weight gain in a concentration-dependent manner (fig. 2a). PAF-induced weight gain was also attenuated by the unspecific calcium channel inhibitor lanthanum chloride (fig. 2b).

One mechanistic explanation for the increased vascular permeability of endothelial cells is endothelial cell contraction and gap formation. This phenomenon is assumed to be at least partly dependent on activation of MLCK [49]. ML-7 is a relatively specific, albeit rather weak, inhibitor of MLCK [50]. Inhibition of MLCK with ML-7 $(35 \mu \mathrm{M})$ reduced PAF-induced oedema formation (fig. 3, table 2) and attenuated the PAFinduced increase in $\mathrm{Kf}_{\mathrm{f}} \mathrm{c}$ (table 2). In contrast, inhibition of CaMKII with K252a (10 nM) resulted in enhanced oedema formation (table 2), an observation which might be explained by the observation that, under certain conditions, CaMKII counter-regulates the action of MLCK [51]. Further experiments with calmidazolium chloride $(10 \mu \mathrm{M})$, an inhibitor of $\mathrm{Ca}^{2+} /$ calmodulin that, amongst other things, also induces
MLCK activation, resulted in strong oedema formation even in the absence of PAF (data not shown).

It was recently shown that thrombin-induced endothelial cell monolayer hyperpermeability results from increased F-actin stress-fibre-related contractile tension, a process regulated by the small GTP-binding protein Rho and ROCK [19]. Y27632 is a

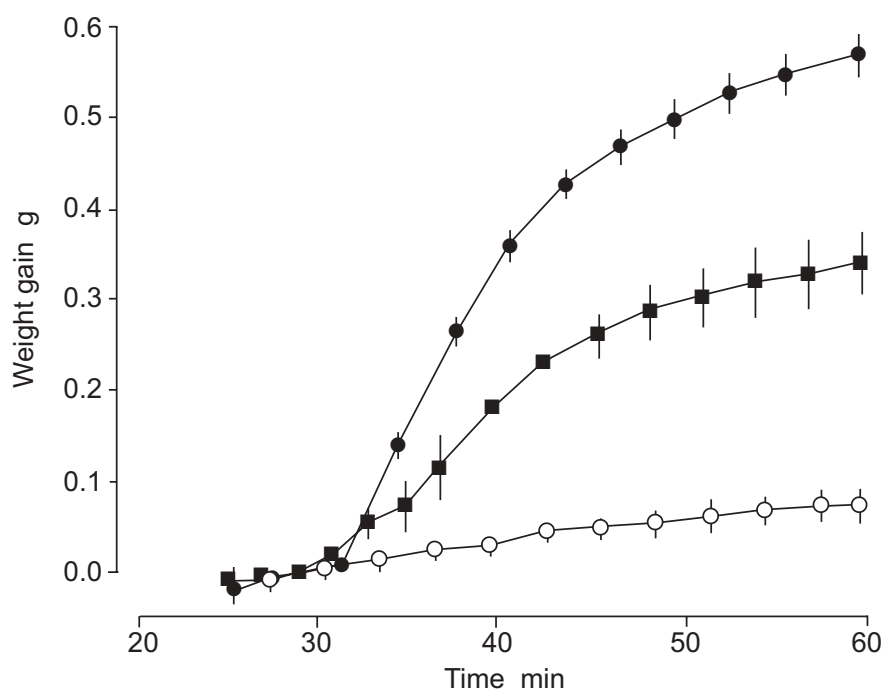

FIGURE 3. Inhibition of myosin light chain kinase (MLCK) reduces plateletactivating factor (PAF)-induced oedema formation ( $\bullet$ : PAF $(n=42)$; $\mathbf{\square}$ : 5iodonaphthalene-1-sulphonyl-homopiperazine (ML-7)+PAF $(n=4) ; 0$ : control $(n=12)$ ). PAF was given as a 5 -nmol bolus injection 30 min after beginning the experiment. The specific MLCK inhibitor ML-7 was administered 10 min before injection of PAF. Data are expressed as mean \pm SEM. Oedema formation in lungs pre-treated with ML-7 and control lungs was significantly reduced compared to PAF alone. 


\begin{tabular}{|c|c|c|c|c|c|}
\hline \multirow[t]{2}{*}{ TABLE 2} & \multicolumn{5}{|c|}{$\begin{array}{l}\text { Platelet-activating factor (PAF)-induced oedema formation: inhibition of myosin light chain kinase and Rho-associated } \\
\text { protein kinase }\end{array}$} \\
\hline & Subjects $n_{1}$ & Weight gain $\mathrm{g}$ & Oedema formation \% & Subjects $\mathrm{n}_{2}$ & $\Delta K \mathrm{f}, \mathrm{c} \mathrm{mL} \cdot \mathrm{min}^{-1} \cdot \mathrm{cmH}_{2} \mathrm{O}^{-1} \cdot 100 \mathrm{~g}^{-1}$ \\
\hline Control & 12 & $0.070 \pm 0.060$ & 0 & 10 & $-0.057 \pm 0.084$ \\
\hline PAF & 42 & $0.589 \pm 0.159$ & 100 & 21 & $0.401 \pm 0.482$ \\
\hline ML-7+PAF & 4 & $0.342 \pm 0.074^{*}$ & 52 & 4 & $0.015 \pm 0.010^{*}$ \\
\hline K252a+PAF & 4 & $0.917 \pm 0.582$ & 163 & 0 & ND \\
\hline
\end{tabular}

Data are presented as mean $\pm \mathrm{SD}$, unless otherwise stated. PAF was given as a 5 -nmol bolus injection 30 min after beginning the perfusion. $\Delta K \mathrm{f}, \mathrm{c}$ : difference in capillary filtration coefficient before and $30 \mathrm{~min}$ after injection of PAF; ML-7: 5-iodonaphthalene-1-sulphonyl-homopiperazine; Y27632: (+)-R-trans-4-(aminoethyl)-N-(4pyridyl)cyclohexanecarboxamide; ND: not determined. ${ }^{`}: 30$ min after application of PAF. *: $p<0.05$ versus PAF.

highly specific ROCK inhibitor that inhibits other kinases such as PKA, PKC and MLCK, but only at concentrations of $>25 \mu \mathrm{M}[30,31]$. Treatment with Y27632 influenced neither PAF-induced weight gain nor the increase in $\mathrm{Kf}_{\text {,c }}$ (table 2).

\section{DISCUSSION}

PAF is an important mediator of oedema formation in many different models of acute lung injury, including endotoxic shock [5, 52], intestinal ischemia-reperfusion [53] and acid instillation [54]. PAF fulfils many of the criteria of a terminal executor of increased vascular permeability: it is formed during inflammation, it increases vascular permeability, and it does so in $<10 \mathrm{~min}$ [6]. The intracellular signalling pathways of PAF-induced oedema formation are only poorly defined. The present findings suggest that part of the PAF-induced pulmonary oedema is mediated via $\mathrm{Ca}^{2+}$-dependent activation of MLCK, the $\mathrm{Ca}^{2+}$ originating from intracellular $\mathrm{IP}_{3}$-sensitive stores and from the extracellular space.

Given the importance of PAF in many models of acute lung injury, surprisingly little is known about the underlying mechanisms. One probable reason for the lack of mechanistic studies is the lack of effect of PAF on endothelial cell permeability in vitro [55-57], although such an effect has been reported once [58]. Therefore, nearly all of the studies on this subject have been performed in isolated organs or whole animals. However, results from whole-animal studies are hard to interpret, partly because the current methods for measuring oedema formation in vivo are not very sensitive, and partly because the haemodynamic changes evoked by PAF make it very difficult to distinguish between permeability and hydrostatic types of oedema. Therefore, many authors have used isolated perfused lungs to study the mechanisms of PAFinduced oedema formation. Such studies have identified several agents that attenuate PAF-induced oedema formation, such as COX inhibitors [5], steroids [6, 59], vitamin $\mathrm{D}_{3}[60]$, agents increasing cyclic adenosine monophosphate levels [61], tricyclodecan-9-yl xanthogenate (D609) and ceramide-specific antibodies [6], but these studies have not yet led to the identification of a specific intracellular signalling mechanism.

At present, only one PAF receptor is known, a typical seventransmembrane domain receptor coupled to $G$ proteins [62]. In mesangial cells, it was shown that activation of this receptor activates PI-PLC to produce $\mathrm{IP}_{3}$ that, upon binding to its receptor, releases $\mathrm{Ca}^{2+}$ from intracellular stores [16, 45]. The present findings in the intact organ are in line with this sequence of events (fig. 4). Inhibition of PI-PLC with L108 and blockade of IP3Rs with xestospongin $\mathrm{C}$ attenuated the PAF-induced oedema formation and increase in Kf,c. L108 and xestospongin $C$ were selected because they are cell permeable and can therefore, be used in studies with intact organs. L108 is also known as ET-18-OCH3 and acts as a proapoptotic agent [63]. In kidney cells, it has been suggested that L108 may activate PAF receptors [63], but since, in the present experiments, L108 had no effect when given alone (it caused neither oedema formation nor contraction of airway or vascular smooth muscle), the present authors do not believe that this happens in the current model. Xestospongin $C(20 \mu \mathrm{M})$ has been shown to discriminate between $\mathrm{IP}_{3}$-sensitive and ryanodine-sensitive $\mathrm{Ca}^{2+}$ stores [64]; however, at least in some tissues, xestospongin C may also block voltage-dependent potassium and calcium channels [65]. Reasonable specificity of xestospongin C and L108 in the present study is suggested by the fact that both inhibitors were used at concentrations only three times greater than their IC50, the observation that both inhibitors failed to affect other responses to PAF (in particular PAF-induced bronchoconstriction) [4], and the fact that the only known common denominator of both inhibitors is inhibition of the $\mathrm{IP}_{3}$ pathway. In addition, both PLC and IP3Rs have been described as targets for quinine, which also reduces PAF-induced oedema formation [7]. Alternative to an increase in $\mathrm{Ca}^{2+}$ concentration caused by response to $\mathrm{IP}_{3}$, intracellular $\mathrm{Ca}^{2+}$ levels might also be increased by ceramide [66], which was recently identified as a mediator of PAF [6]. This interesting possibility needs to be explored further.

The intracellular $\mathrm{Ca}^{2+}$ response to PAF has been shown to be biphasic $[67,68]$. The first phase is mediated by IP3Rs which are regulated by $\mathrm{Ca}^{2+} /$ calmodulin, whereas the second phase occurs due to transmembrane $\mathrm{Ca}^{2+}$ movement. The increase in intracellular $\mathrm{Ca}^{2+}$ concentrations during phase one activates SOCs [43-46]. Alternatively, activation of the PAF receptor may directly activate other calcium channels in the plasma membrane [69]. Manipulation of extracellular $\mathrm{Ca}^{2+}$ content or unspecific inhibition of calcium channels attenuated PAFinduced pulmonary oedema formation (fig. 2). This argues for a role of a capacitive $\mathrm{Ca}^{2+}$ entry through SOCs or receptorcoupled activation of calcium channels in PAF-induced oedema 


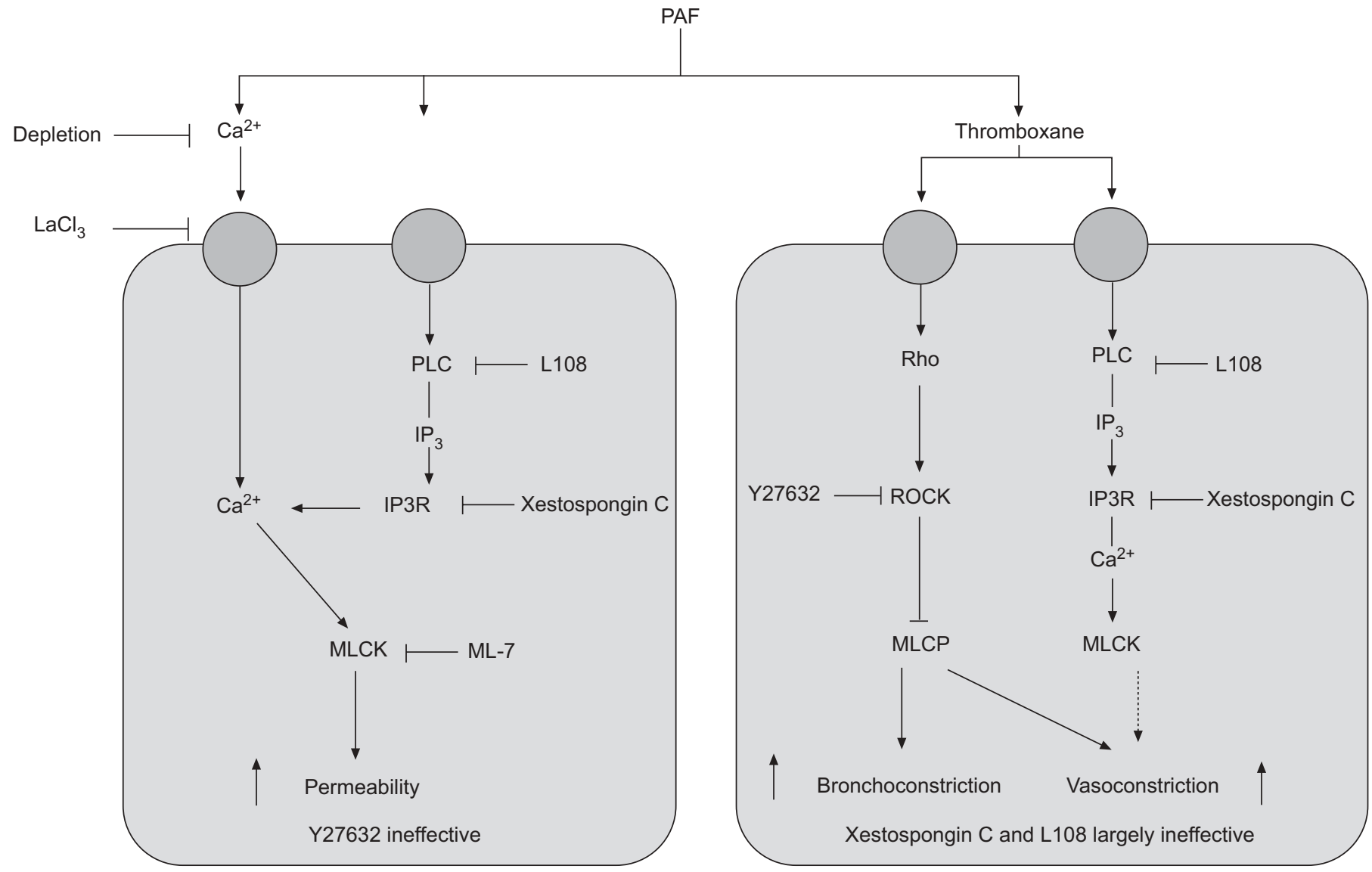

FIGURE 4. Summary of intracellular signalling pathways of rat lungs in response to platelet-activating factor (PAF). The left-hand side shows the effect of PAF on what are presumably endothelial cells as inferred from the present study (for further details, see Discussion section). The right-hand side shows the effect of PAF on what are presumably vascular and airway smooth muscle cells, which is largely mediated by thromboxane. Here, the major pathway is activation of Rho and Rho-associated protein kinases (p160 ROCK), which attenuate the activity of myosin light chain phosphatase (MLCP) with consequent increases in myosin light chain phosphorylation and, hence, contraction [4]. PLC: phospholipase C; $\mathbb{I P}_{3}$ : inositol 1,4,5-trisphosphate; IP3R: $\mathbb{P}_{3}$ receptor; MLCK: myosin light chain kinase; ML-7: 5-iodonaphthalene-1-sulphonylhomopiperazine; L108: edelfosine. — - inhibition; $\uparrow$ : increase or activation.

formation. This interpretation is supported by the finding that thapsigargin, an inhibitor of the endoplasmic reticular $\mathrm{Ca}^{2+}$ adenosine triphosphatase, which leads to emptied intracellular $\mathrm{Ca}^{2+}$ stores and activation of SOCs, induces pulmonary oedema formation by a mechanism that requires extracellular $\mathrm{Ca}^{2+}$ (data not shown) [70].

Increased intracellular $\mathrm{Ca}^{2+}$ concentration activates MLCK, an effect mediated by $\mathrm{Ca}^{2+} /$ calmodulin [71]. In line with this, it was shown that the enhanced permeability induced by PAF was attenuated by pre-treatment with an MLCK inhibitor, indicating that myosin phosphorylation plays an important role in PAF-induced oedema formation. Recently, the significance of the endothelial MLCK in endotoxin-induced pulmonary oedema formation was demonstrated [21]. Since, in this model, PAF is critical to oedema formation $[5,52]$, the blockade of MLCK in that study may also be explained by protection against the effects of PAF.

With respect to myosin light chain phosphorylation, a Rho-kinase-dependent pathway of enhanced permeability [19] and cytoskeletal reorganisation of nonmuscle cells [72] has recently been suggested. CARBAJAL et al. [19] reported that thrombin-induced monolayer hyperpermeability was partially mediated via ROCK. However, in the present study, the specific ROCK inhibitor Y27632 failed to affect PAF-induced weight gain, indicating that Rho kinase does not mediate PAFinduced oedema. The lack of effect of Y27632 on oedema formation is also supported by another recent study showing that, at relevant concentrations, Y27632 does not attenuate airway microvascular leakage evoked by histamine or leukotriene [73]. In both perfused rat lungs and guinea pigs, however, Y27632 was effective in inhibiting airflow obstruction [4, 73]. Taken together, these data suggest that, in the intact organ, the Rho kinase pathway contributes to smooth muscle contraction, but has no role in permeability oedema formation (fig. 4).

Unfortunately, the role of calmodulin could not be explored, because inhibition of $\mathrm{Ca}^{2+}$-binding to calmodulin with calmidazolium caused severe pulmonary oedema of itself. Nevertheless, this is an interesting finding, suggesting that calmodulin is essential for the maintenance of the normal vascular barrier function. CaMKII was reported to counterregulate the action of MLCK in smooth muscle cells. In these experiments, phosphorylation of MLCK decreased the $\mathrm{Ca}^{2+}$ 
sensitivity of myosin light chain phosphorylation [51]. Therefore, inhibition of CaMKII should lead to enhanced MLCK activity. In line with this, blocking CaMKII with K252a resulted in increased oedema formation in the presence of PAF. It is of note that these results were obtained using $10 \mathrm{nM}$ $\mathrm{K} 252 \mathrm{a}$, a concentration at which this inhibitor should not block other enzymes, such as PKA, MLCK and PKC [35, 36]. Again, the present findings are in contrast to observations in endothelial monolayers, in which inhibition of CaMKII reduced thrombin-induced hyperpermeability [74]. Whether these differences are to be attributed to the cell culture model (where PAF does not act) or to differences between thrombin and PAF remains to be elucidated.

Taken together, the present findings suggest that plateletactivating factor activates phosphoinositide-specific phospholipase $C$, which, in turn, produces inositol 1,4,5-trisphosphate. This increase in cytosolic calcium concentration then leads to activation of calcium-gated or receptor-activated calcium channels, leading to a secondary calcium influx from the extracellular space and subsequent activation of myosin light chain kinase.

\section{ACKNOWLEDGEMENTS}

The perfect technical assistance of F. Seel is gratefully acknowledged.

\section{REFERENCES}

1 Hosford D, Koltai M, Paubert-Braquet M, Braquet P. Analysis of platelet-activating factor in endotoxic shock and sepsis using a probability matrix: a critique of metaanalysis. In: Neugebauer EA, Holaday JW, eds. Handbook of Mediators in Septic Shock. Boca Raton, FL, CRC Press, 1994; pp. 439-456.

2 Christie PE, Henderson WR. Lipid inflammatory mediators: leukotrienes, prostaglandins, platelet-activating factor. Clin Allergy Immunol 2002; 16: 233-254.

3 Uhlig S, Wollin L, Wendel A. Contributions of thromboxane and leukotrienes to platelet-activating factor-induced impairment of lung function in the rat. J Appl Physiol 1994; 77: 262-269.

4 Martin C, Göggel R, Ressmeyer AR, Uhlig S. Pressor responses to platelet-activating factor and thromboxane are mediated by Rho-kinase. Am J Physiol Lung Cell Mol Physiol 2004; 287: L250-L257.

5 Göggel R, Hoffman S, Nüsing R, Narumiya S, Uhlig S. PAF-induced pulmonary edema is partly mediated by $\mathrm{PGE}_{2}$, EP3-receptors and potassium channels. Am J Respir Crit Care Med 2002; 166: 657-662.

6 Göggel R, Winoto-Morbach S, Vielhaber G, et al. PAFmediated pulmonary edema: a new role for acid sphingomyelinase and ceramide. Nat Med 2004; 10: 155-160.

7 Falk S, Göggel R, Heydasch U, et al. Quinolines attenuate PAF-induced pulmonary pressor responses and edema formation. Am J Respir Crit Care Med 1999; 160: 1734-1742.

8 Misra UK, Gawdi G, Pizzo SV. Chloroquine, quinine and quinidine inhibit calcium release from macrophage intracellular stores by blocking inositol 1,4,5trisphosphate binding to its receptor. J Cell Biochem 1997; 64: 225-232.
9 Bondeson J, Sundler R. Antimalarial drugs inhibit phospholipase $A_{2}$ activation and induction of interleukin $1 \beta$ and tumor necrosis factor- $\alpha$ in macrophages: implications for their mode of action in rheumatoid arthritis. Gen Pharmacol 1998; 30: 357-366.

10 Kench JG, Seale JP, Temple DM, Tennant C. The effects of non-steroidal inhibitors of phospholipase $\mathrm{A}_{2}$ on leukotriene and histamine release from human and guinea-pig lung. Prostaglandins 1985; 30: 199-208.

11 Shute JK, Smith ME. Inhibition of phosphatidylinositol phosphodiesterase activity in skeletal muscle by metal ions and drugs which block neuromuscular transmission. Biochem Pharmacol 1985; 34: 2471-2475.

12 Rhee SG. Regulation of phosphoinositide-specific phospholipase C. Annu Rev Biochem 2001; 70: 281-312.

13 Rebecchi MJ, Pentyala SN. Structure, function, and control of phosphoinositide-specific phospholipase C. Physiol Rev 2000; 80: 1291-1335.

14 Bolton TB, Prestwich SA, Zholos AV, Gordienko DV. Excitation-contraction coupling in gastrointestinal and other smooth muscles. Annu Rev Physiol 1999; 61: 85-115.

15 Tiruppathi C, Minshall RD, Paria BC, Vogel SM, Malik AB. Role of $\mathrm{Ca}^{2+}$ signaling in the regulation of endothelial permeability. Vascul Pharmacol 2002; 39: 173-185.

16 Kester M, Thomas CP, Wang J, Dunn MJ. Plateletactivating factor stimulates multiple signaling pathways in cultured rat mesangial cells. J Cell Physiol 1992; 153: 244-255.

17 Stevens T, Garcia JG, Shasby DM, Bhattacharya J, Malik AB. Mechanisms regulating endothelial cell barrier function. Am J Physiol Lung Cell Mol Physiol 2000; 279: L419-L422.

18 Garcia JGN, Siflinger-Birnboim A, Bizios R, DelVecchio PJ, Fenton JW, Malik AB. Thrombin-induced increase in albumin permeability across the endothelium. J Cell Physiol 1986; 128: 96-104.

19 Carbajal JM, Gratrix ML, Yu CH, Schaeffer RC. ROCK mediates thrombin's endothelial barrier dysfunction. Am J Physiol Cell Physiol 2000; 279: C195-C204.

20 Dudek SM, Garcia JGN. Cytoskeletal regulation of pulmonary vascular permeability. J Appl Physiol 2001; 91: 1487-1500.

21 Wainwright MS, Rossi J, Schavocky J, et al. Protein kinase involved in lung injury susceptibility: evidence from enzyme isoform genetic knockout and in vivo inhibitor treatment. Proc Natl Acad Sci U S A 2003; 100: 6233-6238.

22 Smith LJ, Rubin AE, Patterson R. Mechanism of platelet activating factor-induced bronchoconstriction in humans. Am Rev Respir Dis 1988; 137: 1015-1019.

23 Prescott SM, Zimmerman GA, Stafforini DM, McIntyre TM. Platelet-activating factor and related lipid mediators. Annu Rev Biochem 2000; 69: 419-445.

24 Sirois MG, de Lima WT, Brum Fernandes AJ, Johnson RJ, Plante GE, Sirois P. Effect of PAF on rat lung vascular permeability: role of platelets and polymorphonuclear leucocytes. Br J Pharmacol 1994; 111: 1111-1116.

25 Toga H, Hibler S, Ibe BO, Usha-Raj J. Vascular effects of platelet-activating factor in lambs: role of cyclo- and lipoxygenase. J Appl Physiol 1992; 73: 2559-2566.

26 Argiolas L, Fabi F, Basso PD. Mechanisms of pulmonary vasoconstriction and bronchoconstriction produced by 
PAF in the guinea-pig: role of platelets and cyclooxygenase metabolites. Br J Pharmacol 1995; 114: 203-209.

27 Chlopicki S, Olszanecki R, Jawien J, Bartus JB, Gryglewski RJ. Residual pulmonary neutrophils are involved in vaso- and bronchoconstrictor responses to platelet activating factor in the isolated buffer-perfused rat lung. Pol J Pharmacol 2000; 52: 217-222.

28 Hamasaki Y, Mojarad M, Saga T, Tai HH, Said SI. Plateletactivating factor raises airway and vascular resistance and induces edema in lungs perfused with platelet-free solution. Am Rev Respir Dis 1984; 129: 742-748.

29 Uhlig S, Heiny O. Measuring the weight of the isolated perfused rat lung during negative pressure ventilation. J Pharmacol Toxicol Methods 1995; 33: 147-152.

30 Davies SP, Reddy H, Caivano M, Cohen P. Specificity and mechanisms of action of some commonly used protein kinase inhibitors. Biochem J 2000; 531: 95-105.

31 Ishizaki T, Uehata M, Tamechika I, et al. Pharmacological properties of Y-27632, a specific inhibitor of Rho-associated kinases. Mol Pharmacol 2000; 57: 976-983.

32 Powis G, Seewald MJ, Gratas C, Melder D, Riebow J, Modest EJ. Selective inhibition of phosphatidylinositol phospholipase $\mathrm{C}$ by cytotoxic ether lipid analogues. Cancer Res 1992; 52: 2835-2840.

33 Saitoh M, Ishikawa T, Matsushima S, Naka M, Hidaka H. Selective inhibition of catalytic activity of smooth muscle myosin light chain kinase. J Biol Chem 1987; 262: 7796-7801.

34 Hashimoto $\mathrm{Y}$, Nakayama T, Teramoto T, et al. Potent and preferential inhibition of $\mathrm{Ca}^{2+} /$ calmodulin-dependent protein kinase II by K252a and its derivative, KT5926. Biochem Biophys Res Commun 1991; 181: 423-429.

35 Kase H, Iwahashi K, Nakanishi S, et al. K-252 compounds, novel and potent inhibitors of protein kinase $\mathrm{C}$ and cyclic nucleotide-dependent protein kinases. Biochem Biophys Res Commun 1987; 142: 436-440.

36 Yamada K, Iwahashi K, Kase H. K252a, a new inhibitor of protein kinase $\mathrm{C}$, concomitantly inhibits $40 \mathrm{~K}$ protein phosphorylation and serotonin secretion in phorbol esterstimulated platelets. Biochem Biophys Res Commun 1987; 144: 35-40.

37 Uhlig S, Wollin L. An improved setup for the isolated perfused rat lung. J Pharmacol Toxicol Methods 1994; 31: 85-94.

38 Uhlig S. The isolated perfused lung. In: Uhlig S, Taylor AE, eds. Methods in Pulmonary Pharmacology. Basle, Birkhäuser, 1998; pp. 29-55.

39 Uhlig S, von Bethmann AN. Determination of vascular compliance, interstitial compliance and capillary filtration coefficient in isolated perfused rat lungs. J Pharmacol Toxicol Methods 1997; 32: 119-127.

40 Benjamini Y, Hochberg Y. Controlling the false discovery rate: a practical and powerful approach to multiple testing. J R Stat Soc Ser B Stat 1995; 57: 289-300.

41 Curran-Everett D. Multiple comparisons: philosophies and illustrations. Am J Physiol Regul Integr Comp Physiol 2000; 279: R1-R8.

42 Isshiki $\mathrm{M}$, Ando J, Korenaga $\mathrm{R}$, et al. Endothelial $\mathrm{Ca}^{2+}$ waves preferentially originate at specific loci in caveolinrich cell edges. Proc Natl Acad Sci U S A 1998; 95: 5009-5014.
43 Kiselyov KI, Semyonova SB, Mamin AG, Mozhayeva GN. Miniature $\mathrm{Ca}^{2+}$ channels in excised plasma-membrane patches: activation by $\mathrm{IP}_{3}$. Pflugers Arch 1999; 437: 305-314.

44 Hocking D, Ferro TJ, Johnson A. Dextran sulfate and heparin inhibit platelet-activating factor-induced pulmonary edema. J Appl Physiol 1992; 72: 179-185.

45 Oshiro T, Kakuta Y, Shimura S, Nara M, Shirato K. Characterization of platelet-activating factor-induced cytosolic calcium mobilization in human eosinophils. Clin Exp Allergy 2000; 30: 699-705.

46 Parekh AB, Penner R. Store depletion and calcium influx. Physiol Rev 1997; 77: 901-930.

47 Clough G. Relationship between microvascular permeability and ultrastructure. Prog Biophys Mol Biol 1991; 55: 47-69.

48 Nicolaysen G. Intravascular concentrations of calcium and magnesium ions and edema formation in isolated lungs. Acta Physiol Scand 1971; 81: 325-339.

49 Garcia JG, Verin AD, Schaphorst KL. Regulation of thrombin-mediated endothelial cell contraction and permeability. Semin Thromb Hemost 1996; 22: 309-315.

50 Bain J, McLauchlan H, Elliott M, Cohen P. The specificities of protein kinase inhibitors: an update. Biochem J 2003; 371: 199-204.

51 Tansey MG, Luby-Phelps K, Kamm KE, Stull JT. Ca ${ }^{2+}$ dependent phosphorylation of myosin light chain kinase decreases the $\mathrm{Ca}^{2+}$ sensitivity of light chain phosphorylation within smooth muscle cells. J Biol Chem 1994; 269: 9912-9920.

52 Chang SW, Feddersen CO, Henson PM, Voelkel NF. Platelet-activating factor mediates hemodynamic changes and lung injury in endotoxin-treated rats. J Clin Invest 1987; 79: 1498-1509.

53 Carter MB, Wilson MA, Wead WB, Garrison RN. Plateletactivating factor mediates pulmonary macromolecular leak following intestinal ischemia-reperfusion. J Surg Res 1996; 60: 403-408.

54 Nagase T, Ishii S, Kume K, et al. Platelet-activating factor mediates acid-induced lung injury in genetically engineered mice. J Clin Invest 1999; 104: 1071-1076.

55 Tschugguel W, Zhegu Z, Gajdzik L, Maier M, Graf J. High precision measurement of electrical resistance across endothelial cell monolayers. Pflugers Arch 1995; 430: 145-147.

56 Uhlig S, Lindner K. Novel mechanisms of endothelial cell permeability in the lung. Lessons from studies with intact lungs and animals. In: Tooke J, Shore A, Whatmore J, eds. The Microcirculation and Vascular Biology. Bologna, Monduzi Editore, 2002; pp. 221-234.

57 Dodam JR, Olson NC, Friedman M. Differential effects of tumor necrosis factor- $\alpha$ and platelet-activating factor on bovine pulmonary artery endothelial cells in vitro. Exp Lung Res 1994; 20: 131-141.

58 Bussolino F, Camussi G, Aglietta M, et al. Human endothelial cells are target for platelet-activating factor. I. Platelet-activating factor induces changes in cytoskeleton structures. J Immunol 1987; 139: 2439-2446.

59 Boschetto P, Rogers DF, Fabbri LM, Barnes PJ. Corticosteroid inhibition of airway microvascular leakage. Am Rev Respir Dis 1991; 143: 605-609. 
60 Chen SF, Ruan YJ. 1 $\alpha, 25$-Dihydroxyvitamin $\mathrm{D}_{3}$ decreases scalding and platelet-activating factor-induced high vascular permeability edema. Pharmacol Toxicol 1995; 76: 365-367.

61 Ortiz JL, Vallés JM, Martí-Cabrera M, Cortijo J, Morcillo EJ. Effects of selective phosphodiesterase inhibitors on platelet-activating factor- and antigen-induced airway hyperreactivity, eosinophil accumulation, and microvascular leakage in guinea pigs. Naunyn Schmiedebergs Arch Pharmacol 1996; 353: 200-206.

62 Chao W, Olson MS. Platelet-activating factor: receptors and signal transduction. Biochem J 1993; 292: 617-629.

63 Mollinedo F, Gajate C, Martin-Santamaria S, Gago F. ET18-OCH3 (edelfosine): a selective antitumour lipid targeting apoptosis through intracellular activation of Fas/CD95 death receptor. Curr Med Chem 2004; 11: 3163-3184.

64 Gafni J, Munsch JA, Lam TH, et al. Xestospongins: potent membrane permeable blockers of the inositol 1,4,5-trisphosphate receptor. Neuron 1997; 19: 723-733.

65 Ozaki H, Hori M, Kim YS, et al. Inhibitory mechanism of xestospongin- $C$ on contraction and ion channels in the intestinal smooth muscle. Br J Pharmacol 2002; 137: 1207-1212.

66 Mihai R, Lai T, Schofield G, Farndon JR. C2-ceramide increases cytoplasmic calcium concentrations in human parathyroid cells. Biochem Biophys Res Commun 2000; 268: 636-641.

67 Stoll LL, Denning GM, Kasner NA, Hunninghake GW. Platelet-activating factor may stimulate both receptordependent and receptor-independent increases in $\left[\mathrm{Ca}^{2+}\right]$ in human airway epithelial cells. I Biol Chem 1994; 269 4254-4259.

68 Katnik C, Nelson DJ. Platelet activating factor-induced increase in cytosolic calcium and transmembrane current in human macrophages. J Membr Biol 1993; 134 213-224.

69 Bkaily G, D'Orleans-Juste P, Naik R, et al. PAF activation of a voltage-gated R-type $\mathrm{Ca}^{2+}$ channel in human and canine aortic endothelial cells. Br J Pharmacol 1993; 110: 519-520.

70 Chetham PM, Babál P, Bridges JP, Moore TM, Stevens T. Segmental regulation of pulmonary vascular permeability by store-operated $\mathrm{Ca}^{2+}$ entry. Am J Physiol 1999; 276: L41-L50.

71 Kamm KE, Stull JT. Dedicated myosin light chain kinases with diverse cellular functions. J Biol Chem 2001; 276: 4527-4530.

72 Fukata Y, Amano M, Kaibuchi K. Rho-Rho-kinase pathway in smooth muscle contraction and cytoskeletal reorganization of non-muscle cells. Trends Pharmacol Sci 2001; 22: 32-39.

73 Tokuyama K, Nishimura H, lizuka K, et al. Effects of Y27632, a Rho/Rho kinase inhibitor, on leukotriene $\mathrm{D}_{4^{-}}$and histamine-induced airflow obstruction and airway microvascular leakage in guinea pigs in vivo. Pharmacology 2002; 64: 189-195.

74 Borbiev T, Verin AD, Shi S, Liu F, Garcia JG. Regulation of endothelial cell barrier function by calcium/calmodulindependent protein kinase II. Am J Physiol Lung Cell Mol Physiol 2001; 280: L983-L990. 